ERJ

Engineering Research Journal

Faculty of Engineering

Minoufiya University

\title{
EXPERIMENTAL STUDY ON THE REHABILITATION OF CORRODED REINFORCED CONCRETE BEAMS USING FIBER REINFORCED POLYMER
}

\author{
A. S. Debaiky 1, Hala.M.R.Abusafa 2, Marwa H. Bondok 3* \\ 1 Associate Prof. in Civil Engineering Department Benha Faculty of Engineering, Benha \\ University, Cairo, Egypt. \\ 2 lecturer. in Civil Engineering Department Benha Faculty of Engineering, Benha University, \\ Cairo, Egypt. \\ 3 Demonstrator in Civil Engineering Department Benha Faculty of Engineering, Benha \\ University, Cairo, Egypt.
}

\begin{abstract}
The purpose of this research is to investigate rehabilitation of corrosion-damaged R.C. beams with carbon fiber reinforced polymer (CFRP) and glass fiber reinforced polymer (GFRP), the effects of CFRP and GFRP amounts on flexural behavior of the beams and summarize the results of a multi-phase experimental program to investigate the viability of using externally bonded fiber reinforced polymer (FRP) laminates to rehabilitate corrosion-damaged reinforced concrete beams. Twenty reinforced concrete test specimens $(100 \times 150 \times 1200 \mathrm{~mm})$ were constructed, ten of them were subjected to an aggressive environment for 13 month, The reinforcement of the four specimens was subjected to accelerated corrosion by means of impressed (D/C) current up to 5\% mass loss, four specimens were not subjected to any corrosion and strengthen by the same schemes of repaired, and the remaining two specimens were not subjected to any corrosion and were not strengthened (control). After being corroded, the beams were repaired by externally epoxy bonding FRP laminates to the concrete surface using two different schemes. Half-cell potential have been measured as metric of performance of the samples. Strain gauges were used on the concrete and FRP laminates to measure strain on beams. The specimens were tested in flexure in a four-point bending system. The results showed that FRP laminates successfully confined the corrosion cracking and spalling due to expansion of corrosion products. The FRP strengthened and repaired beams exhibited increased stiffness and ultimate strength over the unstrengthened specimens. The use of FRP sheets for repairing corroded reinforced concrete beams is an efficient technique to maintain structural integrity and enhance the behavior of such beams.
\end{abstract}

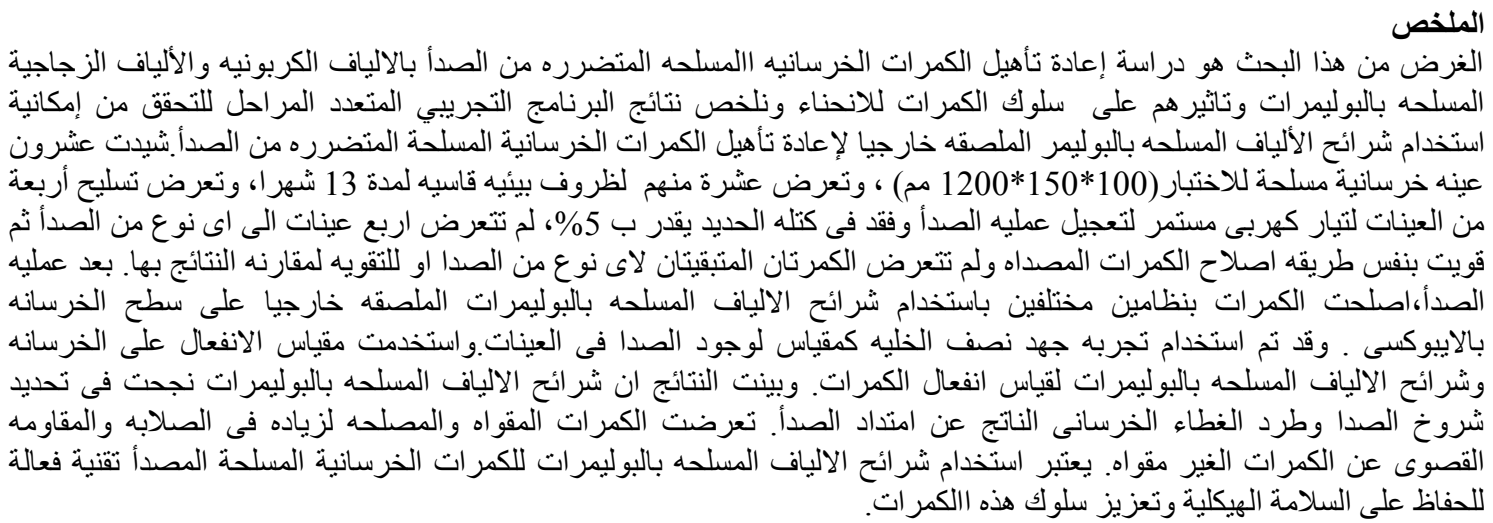

Keywords: FRP; corroded beams; rehabilitation Beams; flexure strength; deflection.

Engineering Research Journal, Vol. 39, No. 1, January 2016, PP: 61-79 


\section{INTRODUCTION}

Corrosion of reinforcing steel is a major problem facing R.C. structures especially of the structures located in the coastal area, marine environment, and bridges for two reasons; firstly as steel corrodes, there is a corresponding drop in the cross-sectional area of the reinforcement bar, thus reducing momentcapacity of the element. Secondly, the corrosion products occupy a larger volume than the original steel which exerts substantial tensile forces on the surrounding concrete and causes it to crack, spall off, in addition to loss of structural bond between the reinforcement and concrete. Resultant Cracks allow moisture and salts to reach the metal surface quickly and easily, thereby increasing rate of corrosion (ACI Committee 222 1996) [1].

This research focuses on using natural environment to create the corrosion in the beams tested. An aggressive environment of high temperature and salt water was used to corrode the reinforced concrete specimens, in addition to using impressed $\mathrm{A} / \mathrm{C}$ current system to create galvanostatic corrosion in some beams tested. Galvanostatic method produces reinforcing corrosion and forces cracks formation in much shorter periods while the natural corrosion taking place in the field over very long period. There are some differences between the two methods in the damage caused, distribution of the corrosion severity and composition of rust products. In the galvanostatic corrosion is significantly different from the real life situation, the natural corrosion products is close to formed in the field with respect to the damage it causes to the structure. Cracks In the galvanostatic corrosion appear parallel to large bars first in beams but in the natural corrosion appear parallel to stirrups first. The main method of detection of corrosion in specimens subjected to an aggressive environment is the half-cell potential (HCP) and the amount of steel dissolving and forming oxides (rust) in specimens was subjected to accelerated corrosion by means of impressed current measured by Faraday's law to metal loss. This research presents experimental study aimed to examine the viability of using FRP wraps to repair reinforced concrete beams subjected to corrosion damage. The FRP systems are promising alternatives for the rehabilitation and strengthening of different concrete structures. Mainly because they are durable, have high strength-to-weight ratio, flexible, high fatigue strength, magnetic neutral, noncorrosive, easy to bond to reinforced concrete beams. FRP improve the corroded element performance of confines the concrete section, thereby controlling corrosion cracking and bond splitting cracks, prevent further chloride, water, and oxygen ingress into concrete, which are required for corrosion reaction to continue, thereby reducing rate of corrosion, and increase flexural and shear resistance to overcome the loss in the steel cross-section. FRP wraps hide surface cracks and rust stains underneath it.

Many studies have been conducted to investigate the effect of using FRP wraps to strengthen or repair reinforced concrete elements subjected to corrosion damage (Bonacci and Maalej, 2000[2]; Sherwood and Soudki, 2000[3]; Masoud et al., 2001[4]; Debaiky et al., 2002[5]; Masoud and Soudki, 2006[6]; ElMaaddawy et al. 2007[7]; Al-Hammoud et al., 2011[8]; P. K. M. Moniruzzaman, 2013[9]).

However, to date, limited information is available in the literature on the viability of using the FRP laminates to repair corrosion damaged R.C. beams corroded using natural method by subjecting specimens to an aggressive environment. Corrosion in the specimens tested was mostly made using the impressed current technique. This research is attempting to fill this gap in the literature.

This research aimed to examine the viability of using FRP wraps to strengthen or repair reinforced concrete beams subjected to natural corrosion damage and compared it with reinforced concrete beams subjected to the galvanostatic corrosion damage.

\section{EXPERIMENAL PROGRAM}

\subsection{Tested specimens:}

In this paper test specimens were fabricated to investigate rehabilitation of the corroded R.C. beams with CFRP and GFRP wrapping. Ten laboratory samples exposed to accelerated corrosion by natural method using a combination of high temperature, humidity, salt water, and wet-dry cycling. Four samples exposed to accelerated corrosion by galvanostatic method using impressed $\mathrm{A} / \mathrm{C}$ current into the reinforcing bars. The six remaining beams were reserved as control specimens. The procedure for monitoring the progression of steel corrosion in concrete is measured by half-cell potential method.

The overall program included 30 small-scale reinforced concrete beams. This paper will present on the monotonic test results from 20 small scale reinforced concrete beams. All specimens used in this program have the same dimensions and reinforcement. Rectangular beam was $100 \mathrm{~mm} \mathrm{x}$ $150 \mathrm{~mm}$ in cross-section and $1200 \mathrm{~mm}$ long for loading span of $1000 \mathrm{~mm}$. The internal longitudinal tensile steel reinforcement consisted of two $10 \mathrm{~mm}$ diameter bars at the bottom (fy $=366.5 \mathrm{MPa}$ ), two 
$6 \mathrm{~mm}$ diameter bars at the top of the beam (fy $=$ $254 \mathrm{MPa}$ ), and 6-mm diameter stirrups at $100 \mathrm{~mm}$ (fy $=254 \mathrm{MPa})$. The shear reinforcements were designed to prevent any premature shear failure. A stainless steel (S.S) $6 \mathrm{~mm}$ diameter rebar was placed $75 \mathrm{~mm}$ above the bottom of the specimen to serve as the cathode for the accelerated corrosion process. The tensile reinforcing steel was extended $20 \mathrm{~mm}$ beyond the end of the concrete, for the purpose of making external electrical connections and permitting the necessary wiring during the corrosion initiation period. The clear concrete cover was $10 \mathrm{~mm}$ on all aspects of the specimen. Fig.1. shows the dimensions and details of reinforcement beam.
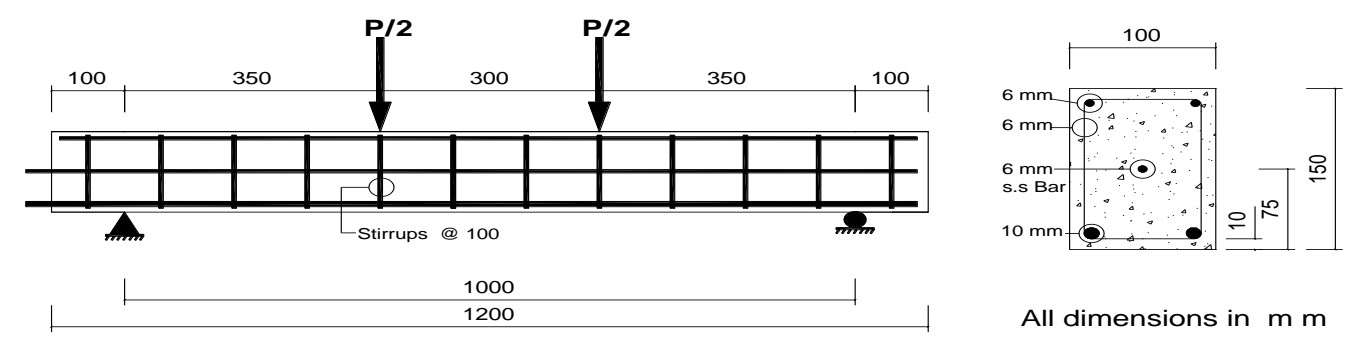

All dimensions in $\mathrm{m} \mathrm{m}$

(a)

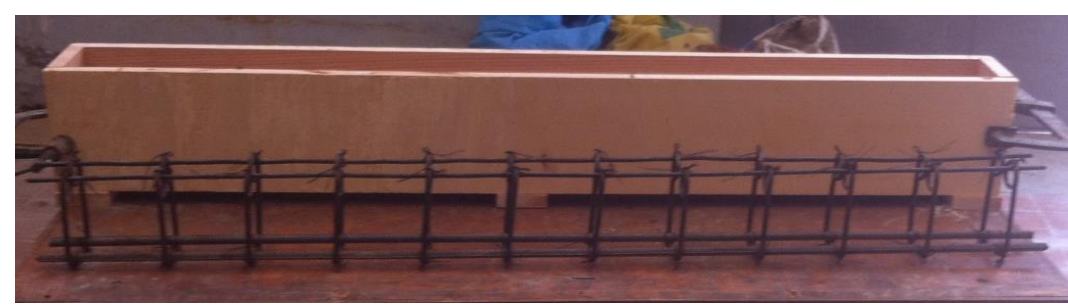

(b)

Fig.1: (a) Dimensions and details of reinforcement of beams. (b) Shows the reinforcement details of the specimens.

\subsection{MATERIAL PROPERTIES}

The test specimens in this investigation were made from low-strength concrete to expedite corrosion process. The specified 28-day compressive strength was $19 \mathrm{MPa}$ (fcu =19 MPA) with a maximum aggregate size of $10 \mathrm{~mm}$. Water containing table salt was added to concrete To make the corrosion initiation period very small except for the control specimens did not contain salt in the concrete mix. The amount of water added was calculated to adjust the water cementing ratio to 0.6 and the amount of table salt added was calculated to have $3 \%$ chlorides by weight of water. The yield strength and the ultimate strength of the main reinforcing rebar were 366.5 $\mathrm{MPa}$ and 536 $\mathrm{MPa}$, respectively. The Glass (GFRP) sheets used in small-scale beams had an ultimate strength of $2250 \mathrm{MPa}$, an elasticity modulus of $70 \mathrm{GPa}$, and an ultimate elongation of $2.8 \%$ as shown in table 1. The Carbon (CFRP) sheets used to strengthen the small -scale beams had an ultimate strength of $3500 \mathrm{MPa}$, an elasticity modulus of 230
$\mathrm{GPa}$, an ultimate elongation of $1.6 \%$ and had a thickness of $0.13 \mathrm{~mm}$ as shown in table 2. The adhesive used for bonding FRP sheets to concrete was a compatible epoxy system provided by the manufacturer. Epoxy resins used in this investigation consist of two compounds solvent free and thixotropic epoxy based impregnating resin / adhesive. They were added together in ratio 4: 1 by weight and mixed rapidly to be assured of homogeneity before using as shown in table 3 .

\subsection{ACCELERATED CORROSION}

The first set of beams was corroded by an aggressive environment of high temperature, humidity, and salty solution. Specimens were placed in two boxes made of plywood and insulated with Plastic sheets and stored it in the open air in order to be affected by weather factors of temperature and humidity as shown in Fig. 2. 
After 300 days, the beams were covered with plastic sheets to create greenhouse effect to keep the temperature required for corrosion as shown in Fig. 3. Corrosion was initiated using the harmful effect of combined wet-dry cycling by sprayed specimens with $3 \% \mathrm{NaCl}$ solution every day in the morning in the wet half-cycle. The atmosphere and weather were used to dry the specimens in the dry half-cycle and allow air intrusion over the entire beams. Each full cycle was exactly one day long. A saline solution of $3 \% \mathrm{NaCl}$ was used in the wet half -cycle. This level of concentration of chlorides was often selected to simulate chloride concentration of seawater.

To make the corrosion initiation period very small used chloride -free in concrete (salt was mixed in the concrete during casting of the beams), the delicate balance of moisture and oxygen required for the corrosion reactions were created by a spraying $\mathrm{NaCl}$ solution, using small concrete cover, high water cement ratio (w/c), and low concrete tensile strength to make the concrete more susceptible to developing cracks at the point when the reinforcement begins to corrode. Cracks, in return, help air ingress into concrete and therefore expedite corrosion rate.

In the second group of galvanostatic corrosion, four beams were subjected to accelerated corrosion by impressing a direct current into the longitudinal bars using an external DC power supply. The longitudinal reinforcing bars were connected to the positive terminal of the DC source to act as anode while the negative terminal was connected to the stainless steel bar (SS) acting as cathode in this artificial corrosion cell.

the amount of steel dissolving and forming oxides (rust) in specimens was subjected to accelerated corrosion by means of impressed current measured by Faraday's law to metal loss; $\Delta \mathrm{m}=\mathrm{MIt} / \mathrm{zF}$. Where $\Delta \mathrm{m}$ is the mass of steel consumed $(\mathrm{g}), \mathrm{M}$ is the atomic weight of metal (56 $\mathrm{g}$ for $\mathrm{Fe}$ ), $\mathrm{I}$ is the current (Amperes), $\mathrm{t}$ is the time (Seconds), $\mathrm{z}$ is the ionic charge (2), and F is Faraday's constant (96500 Amperes. Seconds).

The direct current was impressed through the reinforcing bars at a constant current density of $150 \mu \mathrm{A} / \mathrm{cm} 2$. This value was selected, based on a study by El Maaddawy and Soudki (2007) [7], to produce corrosion cracking similar to those found in the field while corroding the beams in a reasonable time period and make corrosion mechanism and products were closer to those in naturally corroded beams. During accelerated corrosion, the specimens were subjected to wet-dry cycles by spraying it daily with a $3 \% \mathrm{NaCl}$ solution to provide water and oxygen that are essential for the corrosion process. The time and Constant direct current required to corrode the reinforcing steel bars damage with 5\% mass loss was calculated based on Faraday's law then the system was kept for 20 days.

Multiple surface cracks were noticed during corrosion process. Cracks were mainly vertical in line of stirrups and horizontal in line with the two main reinforcing steel bars. Fig.4. shows horizontal and vertical cracks. Half-cell potential readings were taken at the end of natural corrosion process, to determine the corrosion activity. Reading can be related to the probabilities of corrosion using the guidelines in ASTM C876-91.The natural corrosion process lasted 400 day (wet and dry cycles), and resulted in severe corrosion damage to the beams. The galvanostatic corrosion process lasted 20 day, and resulted corrosion damage more severe than natural corrosion process to the beams. Fig.5. shows corroded beams in the end corrosion process with a two method.

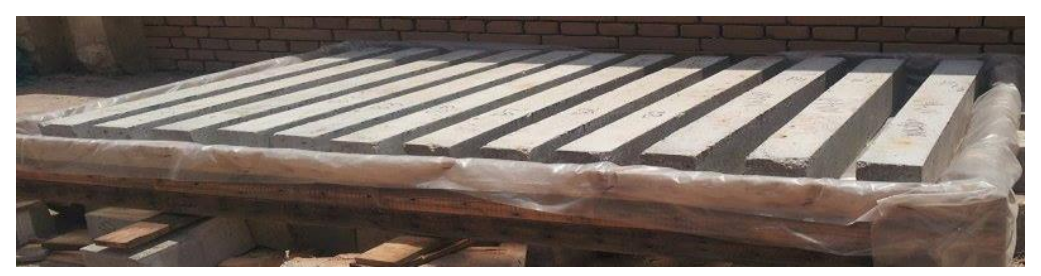

Fig. 2: Beams in group G1 placed in boxes outdoors

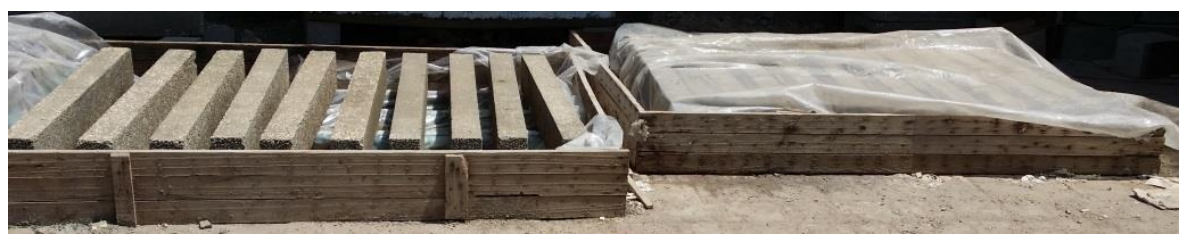

Fig.3: Beams in group G1 placed in boxes outdoorsafter 300 days 
Table 1: Mechanical / Physical properties of adhesive

\begin{tabular}{|l|c|}
\hline \multicolumn{1}{|c|}{ Property } & Value \\
\hline Density & $1.31 \mathrm{~kg} / \mathrm{lt}\left(\mathrm{at}+23^{\circ} \mathrm{C}\right)$ \\
\hline Tensile strength & $30 \mathrm{MPa}\left(7\right.$ days at $\left.+23^{\circ} \mathrm{C}\right)$ \\
\hline Bond strength & $\begin{array}{c}\text { Concrete fracture }(>4 \mathrm{MPa}) \text { on sandblasted substrate: }>1 \\
\text { day }\end{array}$ \\
\hline Elastic modulus & $\begin{array}{c}\text { Flexural }: 3800 \mathrm{MPa}\left(7 \text { days at }+23^{\circ} \mathrm{C}\right) \\
\text { Tensile: } 4500 \mathrm{MPa}\left(7 \text { days at }+23^{\circ} \mathrm{C}\right)\end{array}$ \\
\hline Elongation at break & $0.9 \%\left(7\right.$ days at $\left.+23^{\circ} \mathrm{C}\right)$ \\
\hline
\end{tabular}

Table 2: Mechanical properties of GFRP

\begin{tabular}{|l|c|}
\hline \multicolumn{1}{|c|}{ Property } & Value \\
\hline Fabric length/Roll & $80 \mathrm{~m}$ \\
\hline Fabric width & $500 \mathrm{~mm}$ \\
\hline Fabric design thickness & $0.17 \mathrm{~mm}$ \\
\hline Areal weight & $0.45 \mathrm{~kg} / \mathrm{m} 2$ \\
\hline Fiber Density & $2.56 \mathrm{~g} / \mathrm{cm} 3$ \\
\hline Tensile strength of fibers & $2250 \mathrm{MPa}$ \\
\hline Modulus of elasticity of fibers & $70 \mathrm{GPa}$ \\
\hline Strain at failure of fibers & $2.8 \%$ \\
\hline
\end{tabular}

Table 3: Mechanical properties of CFRP

\begin{tabular}{|l|c|}
\hline \multicolumn{1}{|c|}{ Property } & Value \\
\hline Wrap length/roll & $\geq 50 \mathrm{~m}$ \\
\hline Wrap width & $300 / 600 \mathrm{~mm}$ \\
\hline Wrap thickness & $0.13 \mathrm{~mm}$ \\
\hline Areal weight & $0.230 \mathrm{~kg} / \mathrm{m} 2$ \\
\hline Fibre Density & $1.80 \mathrm{~g} / \mathrm{cm} 3$ \\
\hline Tensile strength of the fibers & $3500 \mathrm{MPa}$ \\
\hline Modulus of elasticity of fibers & $230 \mathrm{GPa}$ \\
\hline Fiber strain when failure & $1.6 \%$ \\
\hline
\end{tabular}




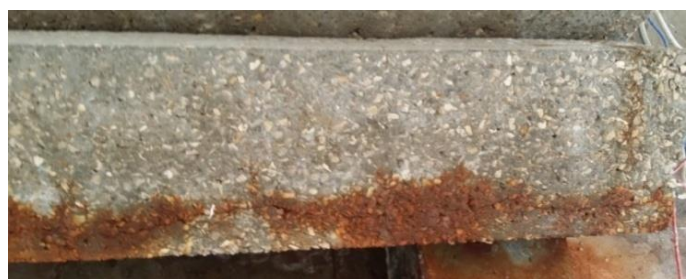

Fig .4: (a) horizontal cracks

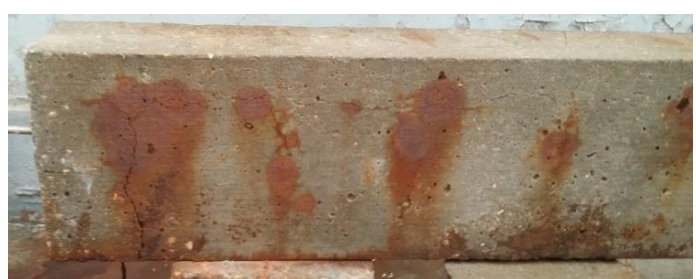

(b) Vertical cracks

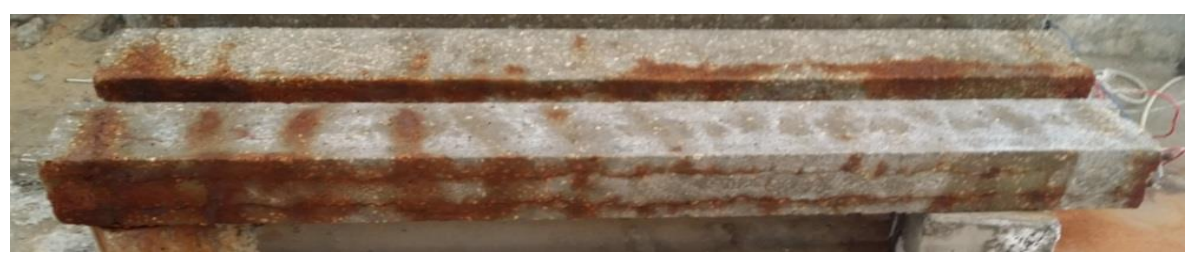

(a)

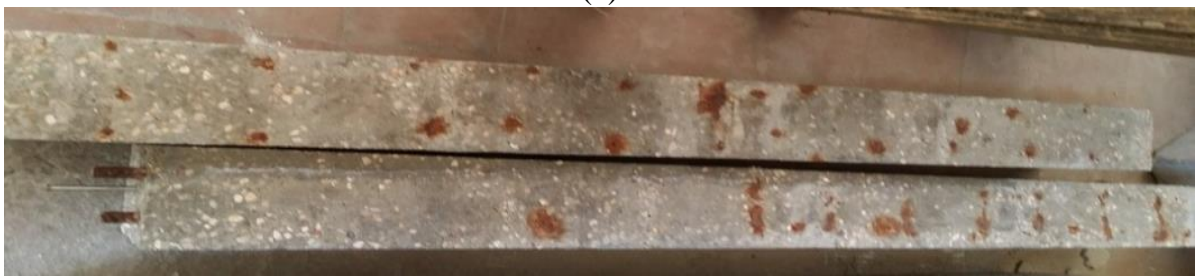

(b)

Fig. 5: (a) typical unwrapped beams after galvanostatic corrosion (b)Typical unwrapped beams after natural corrosion.

\subsection{FRP REPAIR SCHEMES}

The CFRP sheets used in the study were Sika Wrap 230C, GFRP used were Sika Wrap 430G and the epoxy resin used was Sikadur330. Sikadur330 had two components $\mathrm{A}$ and $\mathrm{B}$ that were mixed in $4: 1$ ratio by weight for wrapping the carbon and glass fiber sheets onto concrete. The samples were air dried prior to the application of FRP wraps. The concrete surfaces were ground and cleaned to remove the corrosion staining on the surface to get smooth surface. A grinder was used for rounding off the sharp corners and removing local unevenness from the surfaces. Once the concrete surfaces were prepared, Sikadur330 epoxy resin was placed on the concrete surface. Then the FRP sheet was placed using a steel roller. The pressure and sufficient pull were applied to ensure FRP sheet is impregnated with epoxy, uniform direction of fiber, and absence of wrinkles. After applying the U-wraps, the beams were left for seven days to allow curing of the FRP system. Care was taken to avoid air gaps between the concrete surface and the confining fibers. Some short-term problems such as headache and nausea were encountered during the 24 hours following inhalation of the vapour of epoxy saturate when the safety mask was not used. Corroded specimens were repaired and control specimens were strengthened using the two different schemes of Carbon or Glass FRP sheets.

In the first scheme (scheme Fig.6 (a)), The strengthening and repair used on beams consisted of FRP flexural laminate bonded to the tension face with the fiber orientation in the longitudinal direction followed by transverse laminates bonded to the tension face and up each side of the beam to wrap the full beam with $600 \mathrm{~mm}$ overlap at the ends of the sheet of the middle of top face of beam with the fiber orientation in the transverse direction. The transverse laminates work as anchor to the flexural laminate along the whole length of the beam and thus preventing, premature delamination.

In the second scheme (scheme Fig.6 (b)), FRP sheets were applied for repair and strengthening consisted of intermittent U-shaped $400 \mathrm{~mm}$ wide strips around the tension face and the sides to wrap the full beam perimeter with $600 \mathrm{~mm}$ overlap at the ends of the sheet at the middle of top face of beam in flexural strengthening at mid-span of the corroded specimen (pure flexure zone) and four strips $50 \mathrm{~mm}$ with wide 
on the two sides (in the shear span). The spacing between the U-wrap was kept constant at 100mm.

These repair and strengthening schemes are illustrated in Fig.6. The repair and strengthening of specimens in laboratory is illustrated in Fig.7.Table 4 shows the experimental test program.

Table 4: The experimental test program.

\begin{tabular}{|c|c|c|c|c|c|c|}
\hline $\begin{array}{l}\text { Group } \\
\text { No. }\end{array}$ & $\begin{array}{l}\text { Wrapped } \\
\text { or exposed }\end{array}$ & $\begin{array}{l}\text { No. of } \\
\text { beams }\end{array}$ & Designation & $\begin{array}{l}\text { scheme of } \\
\text { wrapping }\end{array}$ & $\begin{array}{l}\text { type of } \\
\text { Fiber }\end{array}$ & comments \\
\hline control & exposed & 2 & $\mathrm{CE}$ & -------- & -------- & \multirow{5}{*}{ tested at 400 days } \\
\hline \multirow{4}{*}{ 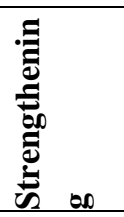 } & \multirow{4}{*}{ Wrapped } & 1 & CE FC & 1 & Carbon & \\
\hline & & 1 & CE FG & 1 & Glass & \\
\hline & & 1 & CE PC & 2 & Carbon & \\
\hline & & 1 & CE PG & 2 & Glass & \\
\hline \multirow{5}{*}{ 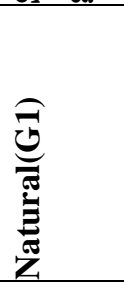 } & exposed & 2 & NE1 & -------- & ------- & tested at 400 days \\
\hline & \multirow{4}{*}{ Wrapped } & 2 & NE/W FC/400/400 & 1 & Carbon & \multirow{4}{*}{ tested at 400 days } \\
\hline & & 2 & NE/W FG/400/400 & 1 & Glass & \\
\hline & & 2 & NE/W PC/400/400 & 2 & Carbon & \\
\hline & & 2 & NE/W PG/400/400 & 2 & Glass & \\
\hline \multirow{4}{*}{ 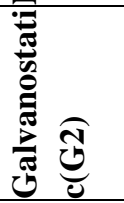 } & exposed & 1 & AE-1 & -------- & -------- & \multirow{4}{*}{ tested at 400 days } \\
\hline & \multirow{3}{*}{ Wrapped } & 1 & AE-2 & ------- & ------- & \\
\hline & & 1 & $\mathrm{AE} / \mathrm{W} \mathrm{PC}$ & 2 & Carbon & \\
\hline & & 1 & AE/W PG & 2 & Glass & \\
\hline
\end{tabular}

The following symbols will be used to describe the conditions of beams:

\section{C: $\quad$ Carbon fiber}

G: Glass fiber

$\mathrm{N}$ : Natural severe environment

A: Accelerated Galvanostatic system

E: $\quad$ Exposed

W: Wrapped

F: $\quad$ Full wrap over the length

P: $\quad$ Part wrap
X/Y: Age when wrapped / age when tested. Each exposed (un wrapped) beam two strain electric gauges, (60mm length and $120 \Omega$ resistance) installed in mid-span and in $150 \mathrm{~mm}$ from the center to measure the strain in the concrete.

Wrapped beams was equipped with one Strain gauge, (20 mm length and $120 \Omega$ resistance) was installed in mid-span to measure the strain in the fibre during loading. 


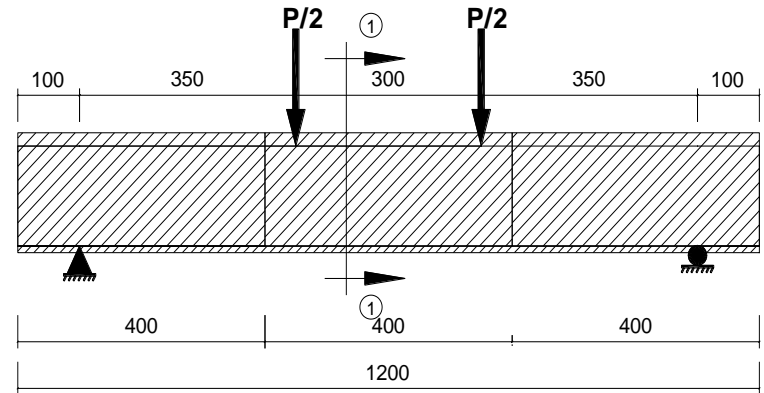

(a) The first scheme (scheme I)

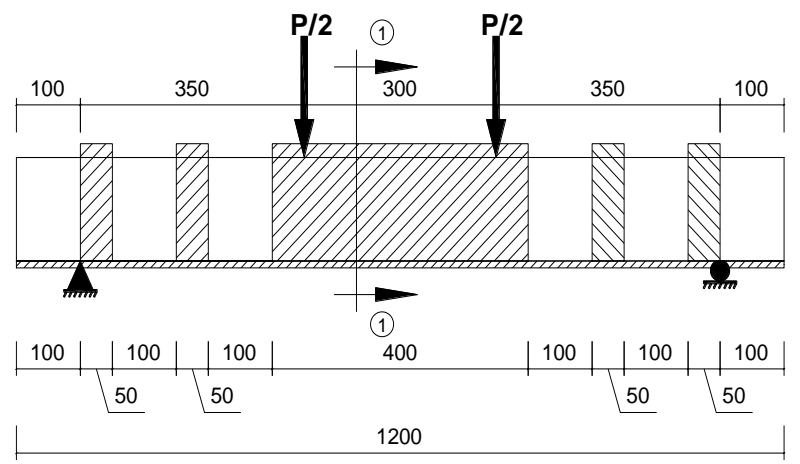

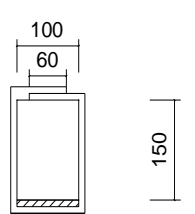

$\sec 1-1$

All dimensions in $\mathrm{m} \mathrm{m}$

(b) The second scheme (scheme II)

Fig .6: The repair and strengthening schemes.
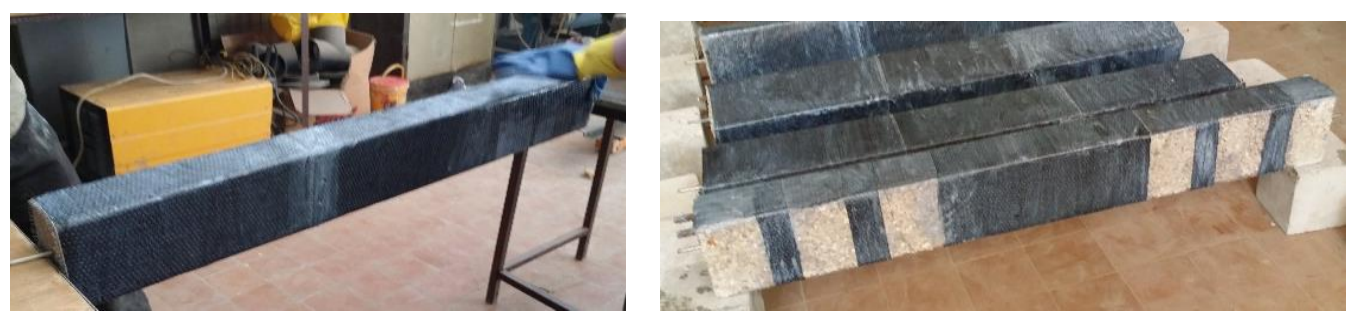

Fig.7: Illustrated the repair and strengthening of specimens in the laboratory.

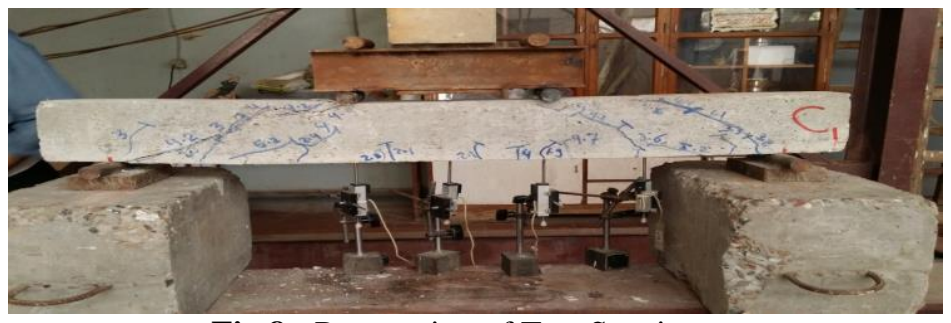

Fig.8: Preparation of Test Specimens 


\subsection{TEST SETUP AND TESTING PROCEDURE}

The load was applied using a hydraulic jack of 800 $\mathrm{kN}$ capacity, load was applied manually and measured using load cell connected to data equitation system. The readings were recorded on excel sheet on computer. The applied load was equally distributed on two concentrated points using spreader beam.

The specimens were prepared for testing as a simply supported under four point bending. The beams were simply supported over a clear span of $1000 \mathrm{~mm}$. A spreader beam was used to transfer the load to the test specimen through two loading points $300 \mathrm{~mm}$ in mid span of beam.

Four linear variable differential transducers (LVDTs)mounted at the bottom soffit of the beam for measuring deflections at bottom face of the beams (tension side), placed at the mid-span, under the two load application points, and half way between one bending point and support. Schematic arrangement of loading for the tested beams is shown in Fig.8.

\section{EXPERIMENTAL RESULTS AND DISCUSSION:}

The experimental results including ultimate loads, corresponding deflection at mid-point, corresponding strain at mid-point, and failure modes for the beam specimens are summarized in Table 5. The results obtained from these tests are analyzed in the following.

Table 5: Experimental results specimens

\begin{tabular}{|c|c|c|c|c|c|}
\hline Group & specimens & $\begin{array}{c}\text { ultimate } \\
\text { loads } \\
(\mathrm{Pu}) \\
(\mathrm{kN})\end{array}$ & $\begin{array}{c}\text { Gained } \\
\text { Strength } \\
(\mathbf{k N})\end{array}$ & $\begin{array}{l}\text { Average def. } \\
\text { at mid-point } \\
\text { at max load. } \\
\quad(\mathrm{mm})\end{array}$ & failure mode \\
\hline \multirow[t]{2}{*}{ control } & CE-1 & 52.3 & 0 & 8.05 & Flexural failure \\
\hline & CE-2 & 49.6 & ----------- & 7.65 & Flexural failure \\
\hline \multirow[t]{4}{*}{ Strengthening } & CE- FC & 82 & 29.7 & 11.98 & Flexural failure \\
\hline & CE- FG & 83.4 & 31.1 & 17.33 & Flexural failure \\
\hline & CE- PC & 77.2 & 24.9 & 12.93 & Shear failure \\
\hline & CE- PG & 66.4 & 14.1 & 11.05 & Shear failure \\
\hline \multirow{10}{*}{ natural } & NE1-1 & 48.6 & 0 & 6.02 & Shear failure \\
\hline & NE1-2 & 60.2 & ----------- & 6.14 & Shear failure \\
\hline & NE/W FC/400/400-1 & 80.5 & 31.9 & 12.12 & Flexural failure \\
\hline & NE/W FC/400/400-2 & 84.9 & 36.3 & 9.84 & Flexural failure \\
\hline & NE/W FG/400/400-1 & 86.3 & 37.7 & 15.65 & Flexural failure \\
\hline & NE/W FG/400/400-2 & 80.5 & 31.9 & 14.25 & Flexural failure \\
\hline & NE/W PC/400/400-1 & 75.8 & 27.2 & 10.07 & Flexural failure \\
\hline & NE/W PC/400/400-2 & 79.7 & 31.1 & 10.49 & Flexural failure \\
\hline & NE/W PG/400/400-1 & 73.7 & 25.1 & 21.65 & Flexural failure \\
\hline & NE/W PG/400/400-2 & 87.4 & 38.8 & 15.17 & Flexural failure \\
\hline \multirow[t]{4}{*}{ Galvanostatic } & AE-1 & 35.9 & ----------- & 6.34 & Shear failure \\
\hline & $\mathrm{AE}-2$ & 24.65 & 0 & 6.79 & Shear failure \\
\hline & AE/W PC & 50.62 & 25.97 & 10.71 & Shear failure \\
\hline & AE/W PG & 31.1 & 6.45 & 13.18 & Shear failure \\
\hline
\end{tabular}

\subsection{Ultimate Load:}

The ultimate capacity $(\mathrm{Pu})$ of each beam was determined by the peak load attained during loading test. The data collected to determine the increasing of the ultimate capacity of beams due to strengthening and repairing beams with CFRP and GFRP using two schemes (full and partial wrap). 


\subsubsection{CONTROL AND STRENGTHENING BEAM}

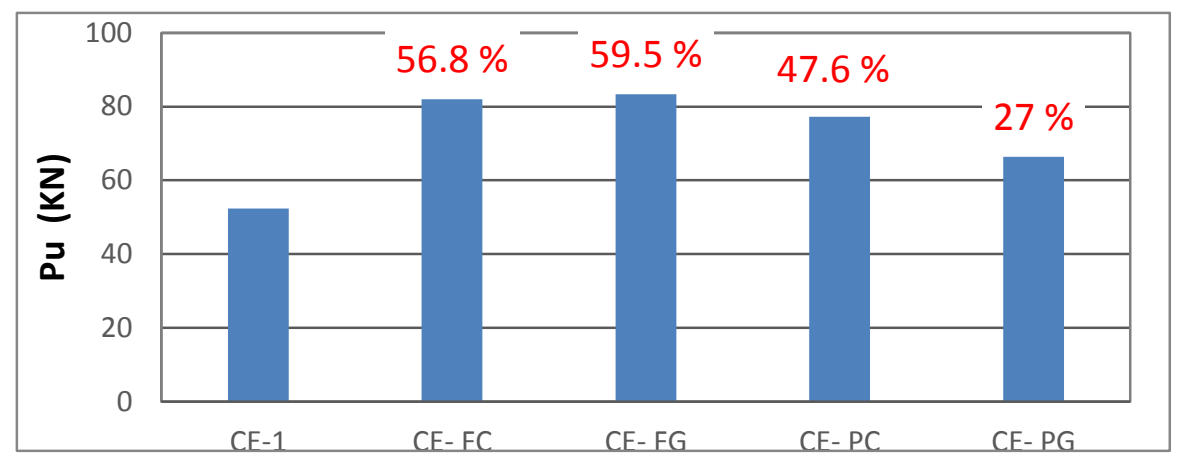

Fig. 9: Ultimate Load Comparison of Beams.

The above result show that the ultimate capacity of the R.C beams strengthened by external CFRP wrapping is greater than beams strengthened by GFRP in (scheme II), full wrap specimens over the length (scheme I) give Results higher than part wrap specimens (scheme II).but, Scheme II give significantly improved in the ultimate load capacity as shown in Fig. 9 .

\subsubsection{Natural Corrosion Process}

The data collected to determine the reduction in the ultimate capacity of beams due to corrosion. The
Natural corrosion beams (G1) which have corrosion damage during large period showed a poorer performance when compared to controls beams which have not corrosion damage. Increasing corrosion damage with time resulted poorer flexural performance of beams as shown in Fig. 10.

The above results show that the ultimate capacity of the R.C beams repaired by external CFRP wrapping are greater than the control beam and greater than corroded unwrapped beam by average $70.15 \%$ for (scheme I) and $60 \%$ for (scheme II).

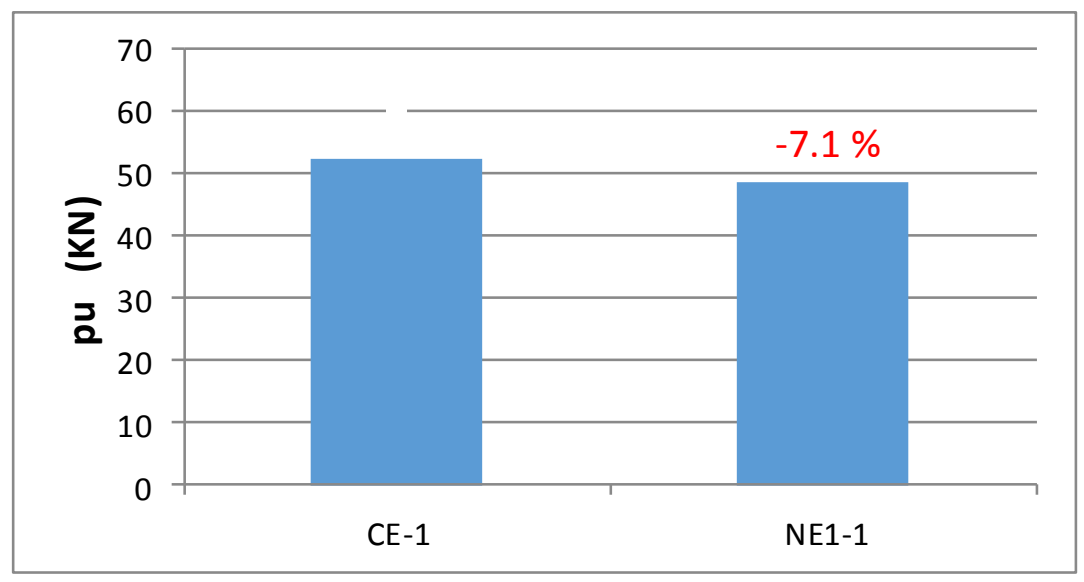

Fig.10: Ultimate Load Comparison of Beams (CE-1) and (NE1-1). 


\subsubsection{Beams Repaired using CFRP:}

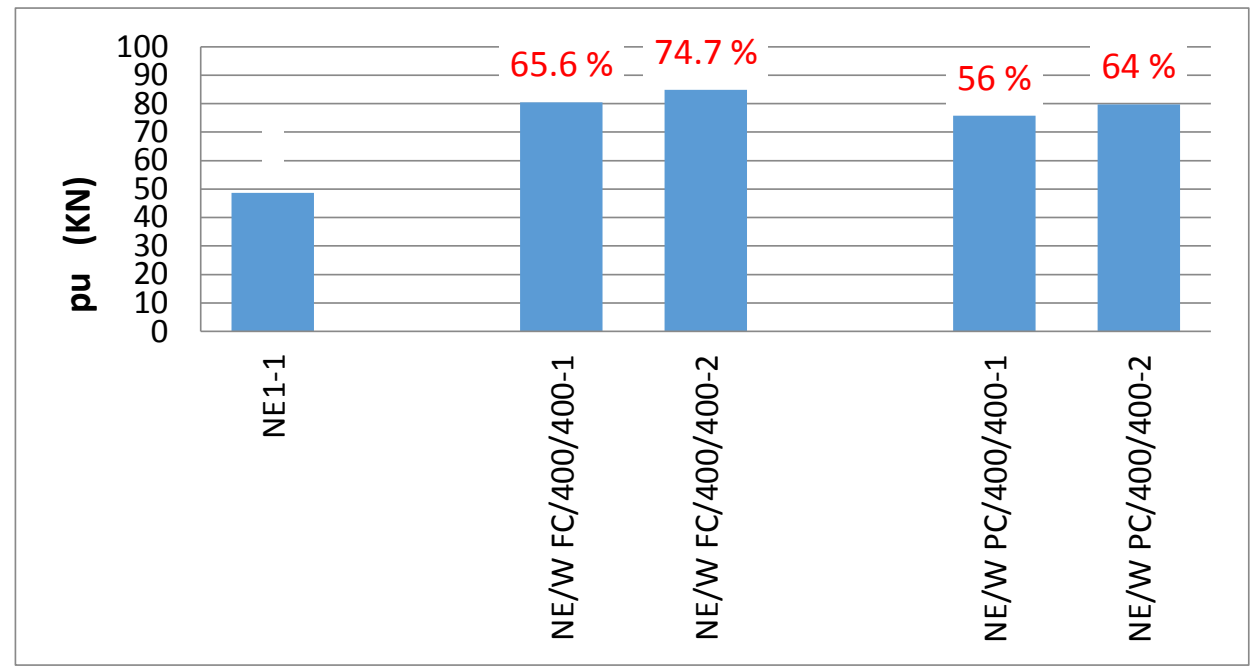

Fig.11: Ultimate Load Comparison of Beams.

Full wrap specimens over the length (scheme I) give Results higher than part wrap specimens (scheme II). Scheme II give a major increase and significantly improved in the ultimate load capacity compared to no repaired beam, lower in cost, and easy in application, therefore I prefer to use it in retrofitting the ultimate capacity of natural corroded beams as shown in Fig. 11.

\subsubsection{Beams Repaired using GFRP:}

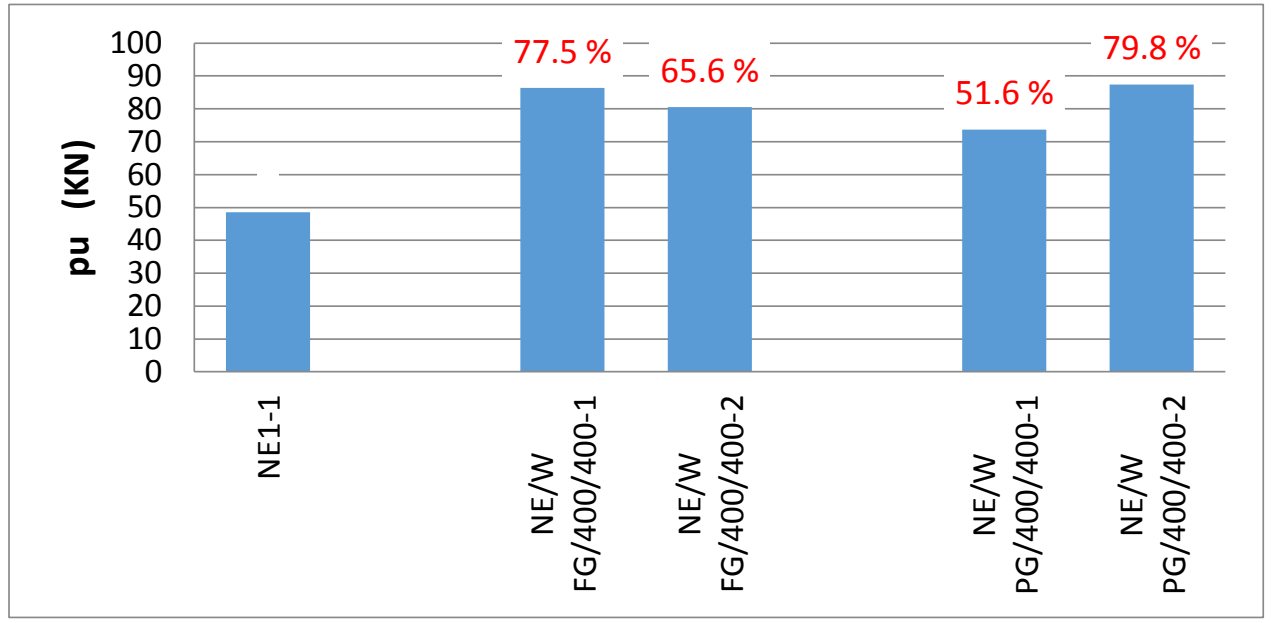

Fig.12: Ultimate Load Comparison of Beams.

The above results show that the ultimate capacity of the R.C. beams repaired by external GFRP wrapping is greater than the control beams and greater than corroded unwrapped beam by average $71.55 \%$ for (scheme I)and $65.7 \%$ for (scheme II), full wrap specimens over the length (scheme I) give Results slightly higher than part wrap specimens (scheme II).
Scheme II give a major increase and significantly improved in the ultimate load capacity, lower in cost, and easy in application, therefore it is preferred to use it in retrofitting the ultimate capacity of natural corroded beams as shown in Fig. 12. 


\subsubsection{Comparison between CFRP and GFRP:}

For scheme I, The CFRP repaired beams and GFRP repaired beams were showed an increase in ultimate load carrying capacity by average $70.15 \%$ and 71.55 $\%$ respectively compared to corroded unwrapped beam.

For scheme II, The CFRP repaired beams and GFRP repaired beams showed an increase in ultimate load carrying capacity by average $60 \%$ and $65.7 \%$ respectively compared to corroded unwrapped beam. The above results show that using GFRP is better than using CFRP in rehabilitation natural (400/400) corroded beams in two schemes wrapping and GFRP is lower cost than CFRP.

\subsubsection{Galvanostatic Corrosion Process:}

The data collected to determine the lessening of the ultimate capacity of beams due to galvanostatic corrosion. The galvanostatic corrosion beams (G2) which have corrosion damage showed Avery poorer performance when compared to control beam which have not corrosion damage as shown in Fig. 13.

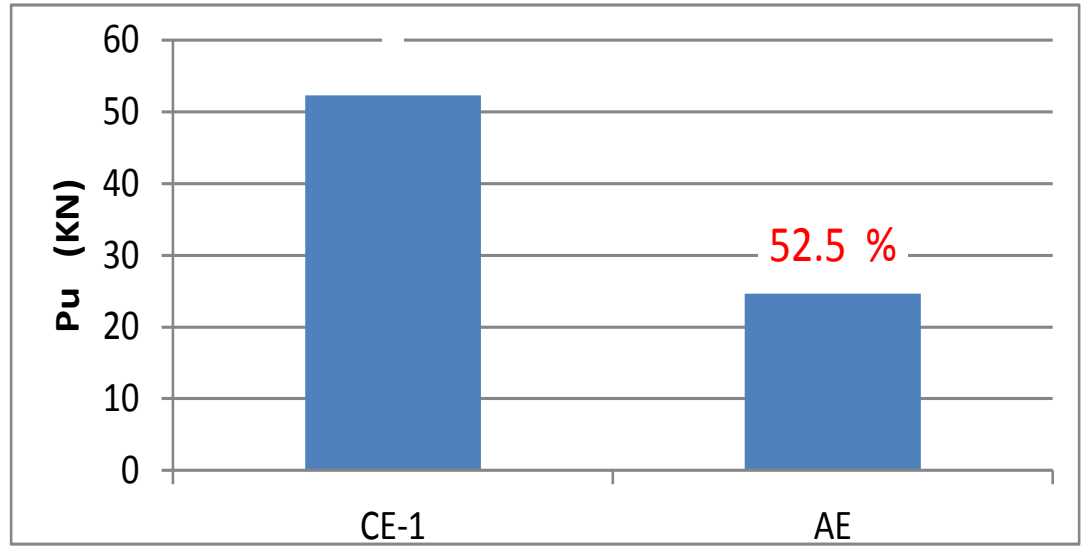

Fig.13: Ultimate Load Comparison of Beams (CE-1) and (AE).

\subsubsection{Repaired with part wrap (scheme II) by using CFRP and GFRP:}

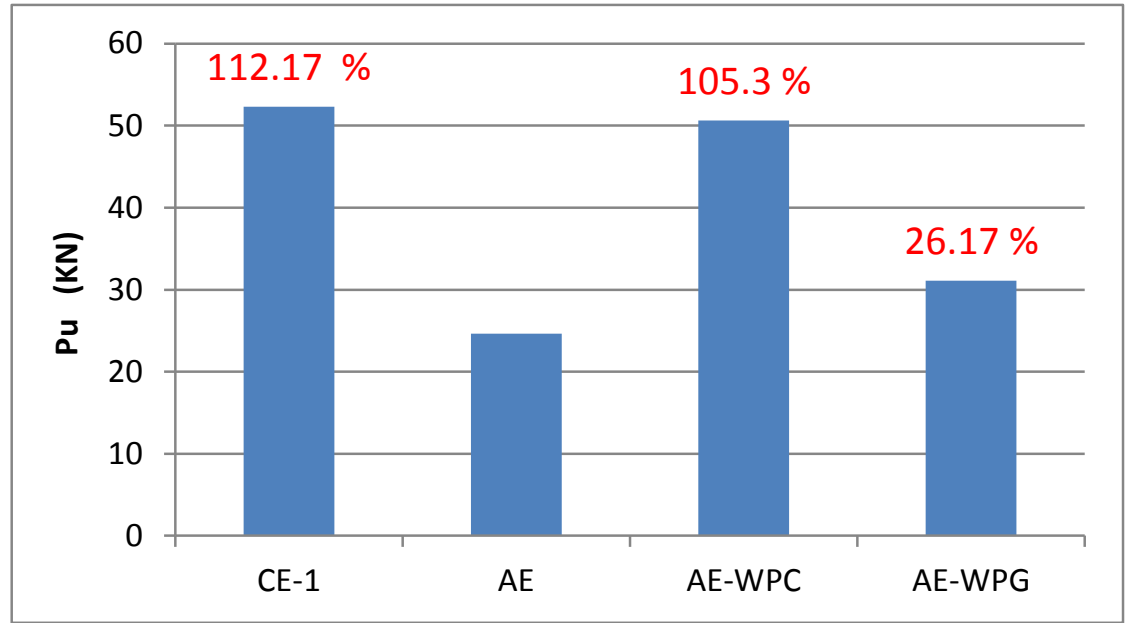

Fig.14: Ultimate Load Comparison of Beams (CE-1), (AE), (AE- WPC), (and (AE- WPG). 
The above result show that the ultimate capacity of the reinforced concrete beams repaired by external CFRP wrapping is greater than the galvanostatic corrosion beam and slightly lower than the control beam, and beam repaired by external GFRP wrapping is slightly greater than that for the galvanostatic corrosion beam and Very less than that for the control beam, It is seen that the ultimate capacity of beam (AE/WPC) (have part wrap with CFRP) is satisfactory in comparison with the reference beam
(AE-2), therefore It is preferred to use CFRP in retrofitting the ultimate capacity of galvanostatic corroded beams as shown in Fig. 15.

\subsection{Deflection:}

Deflection is an important parameter that was measured during the testing of beams. The loaddeflection behavior for the retrofitted beam specimens with one layer of CFRP and GFRP sheets are shown in Fig.14 to Fig.19.

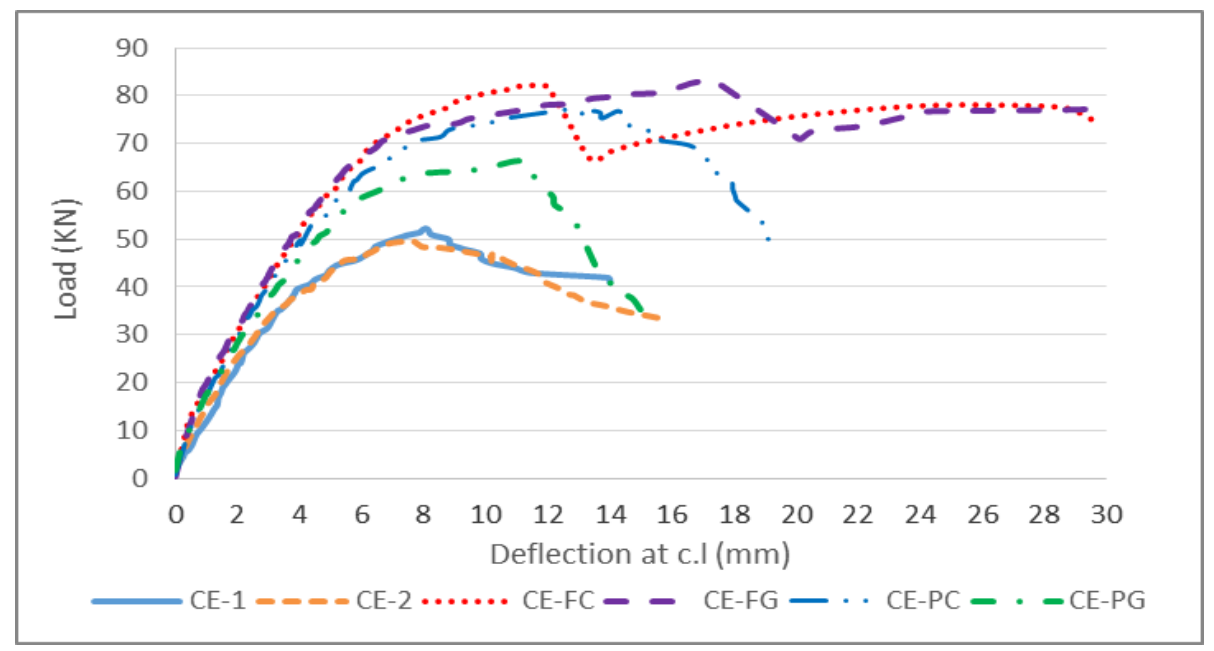

Fig. 15: Load-Deflection curves for specimens.

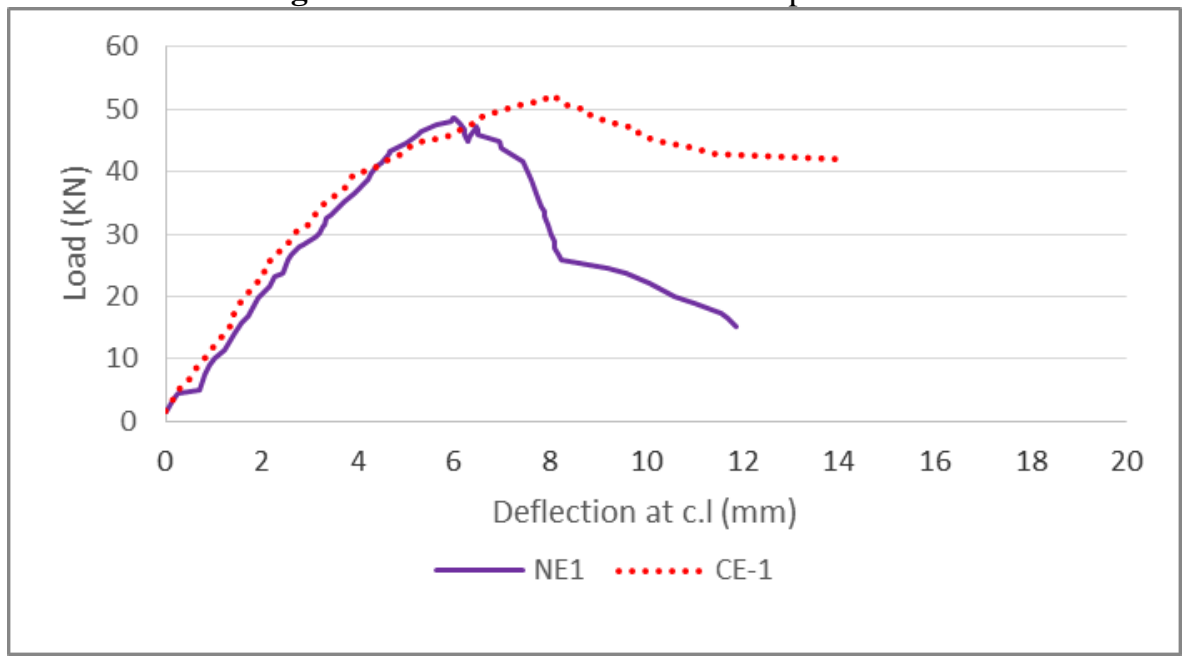

Fig. 16: Load-Deflection curves for specimens. 


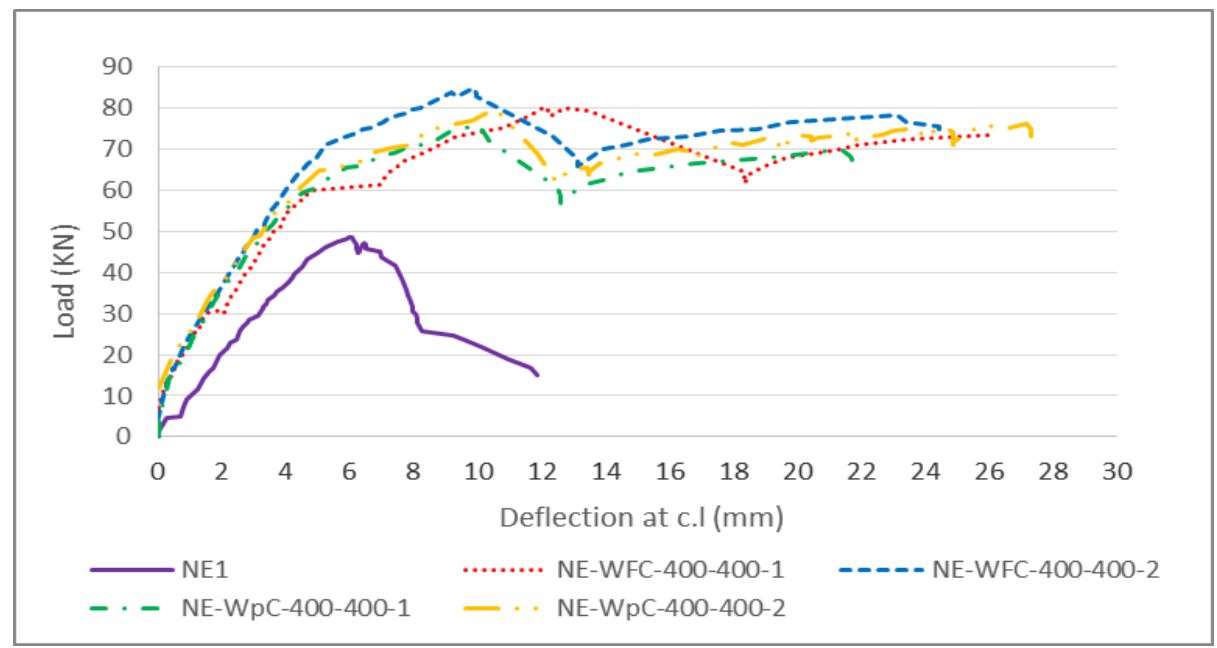

Fig. 17: Load-Deflection curves for specimens.

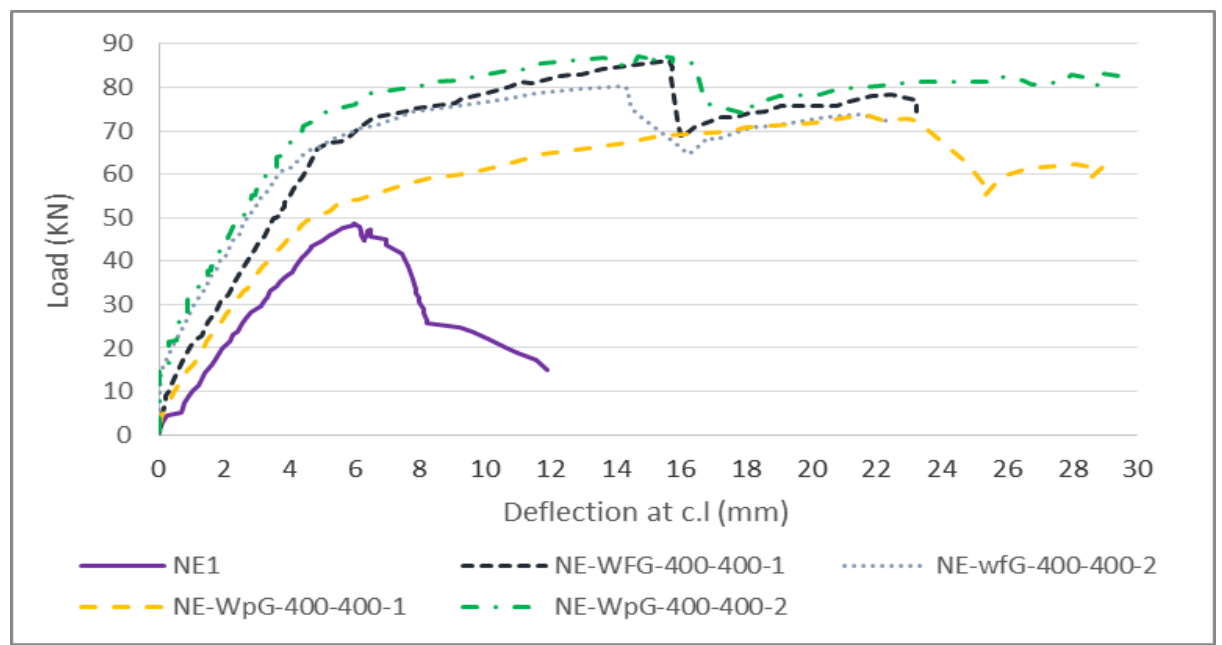

Fig. 18: Load-Deflection curves for specimens.

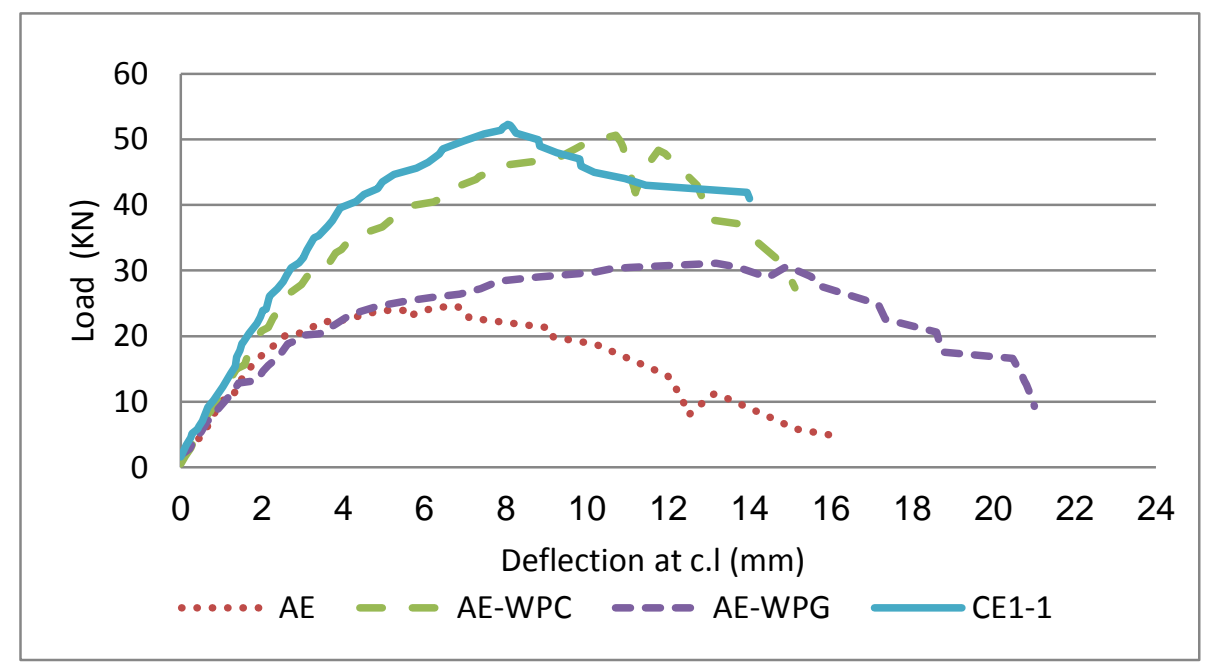

Fig. 19: Load-Deflection curves for specimens. 
As shown in the curves of load - mid span deflection, FRP wrapping strengthened and repaired beams significantly improved both ultimate load, deflections, and flexural rigidity prior to failure of beam which were greater than of the control beam and corroded no wrapped beam, the use of FRP sheets produced lower deflection for the same load up till failure than control, for all stages of loading up to failure.

As shown in the curves galvanostatic corrosion process, CFRP repaired specimen is slightly lower than control beam and GFRP repaired specimen is Very less than the control beam, so we cannot use one layer of FRP with part wrap to rehabilitation beams with high corrosion, we should increase the number of layers of FRP and use full wrap.

\subsection{Ductility Ratio:}

Ductility is one of the most important parameters to reflect the plastic deformability of members and structures. The displacement ductility ratio $[\mu \mathrm{D}]$ can be calculated as $[\Delta \mathrm{u} / \Delta \mathrm{cr}]$, where $[\Delta \mathrm{u}]$ is the midspan deflection at the maximum recorded load capacity and $[\Delta \mathrm{cr}]$ is the mid-span deflection corresponding to cracking load $[\Delta \mathrm{cr}]$ as shown in Table 3 and fig. 20 .

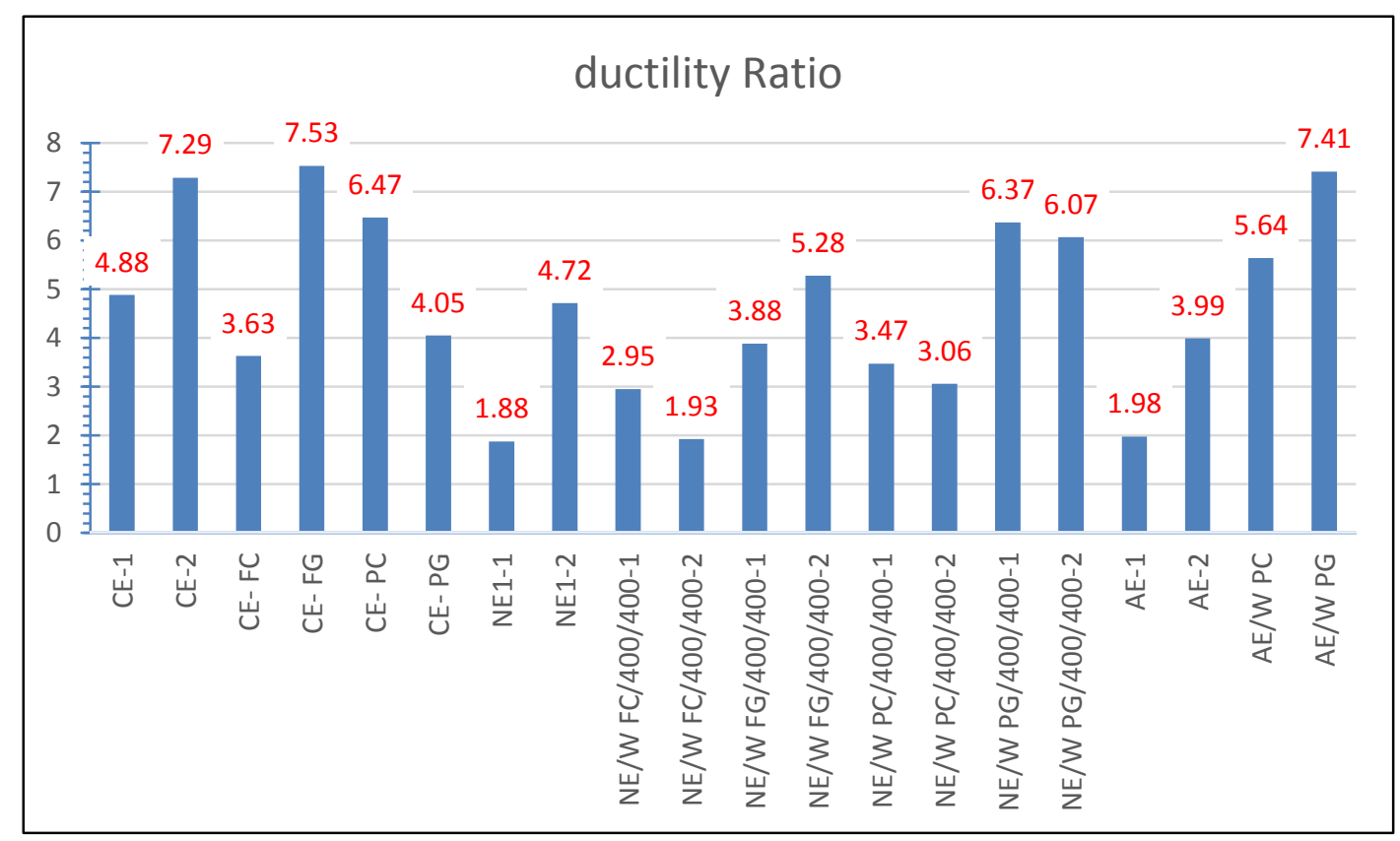

Fig.20: the ductility Ratio for specimens.

In general, the corroded un wrapped specimens (NE11, NE1-2, NE2-1, NE2-2) showed higher reduction in ductility when compared with their corresponding reference without corrosion (control) (CE-1, CE-2). It was observed that the ductility ratio of the beam (NE1, NE-2) decreased to about $50 \%$ of the similar reference beam (CE-1, CE-2). The reduction in the ductility of beams was due to increasing corrosion.

For all strengthened beams(CE-FC, CE-FG, CE-PC, CE-PG), it is clearly show that strengthening with externally bonded FRP laminates under sustaining loads can reduce the ductility of the strengthened beams by comparison with the control beam (CE-1).
The percentage of reduction ductility ratio depends on the type and method of wrapping with FRP.

In natural corrosion process (400/400), The result indicates that the use of FRP in rehabilitation corroded beams within the studied range can increase the ductility index, but the beam (NE/WFC/400/4002) recorded reduction in ductility ratio $(\mu \mathrm{D})$ about $0.26 \%$ compared to the similar reference beam (NE1).

In galvanostatic corrosion process, the beam with GFRP part wrapping (AE/WPG) showed ductility ratio $(\mu \mathrm{D})$ somewhat closer to the beam with CFRP part wrapping (AE/WPC). Wrapped beams showed 
an acceptable increased ductility in comparison with that of the corresponding reference beam.

\subsection{Energy Absorption:}

The energy absorption of a beam can be expressed based on deflection of the beam. The energy absorption was obtained by calculating the entire area under the load-deflection curve up to $25 \%$ deflection at maximum load for each beam as shown in Table 3 and fig. 21 .

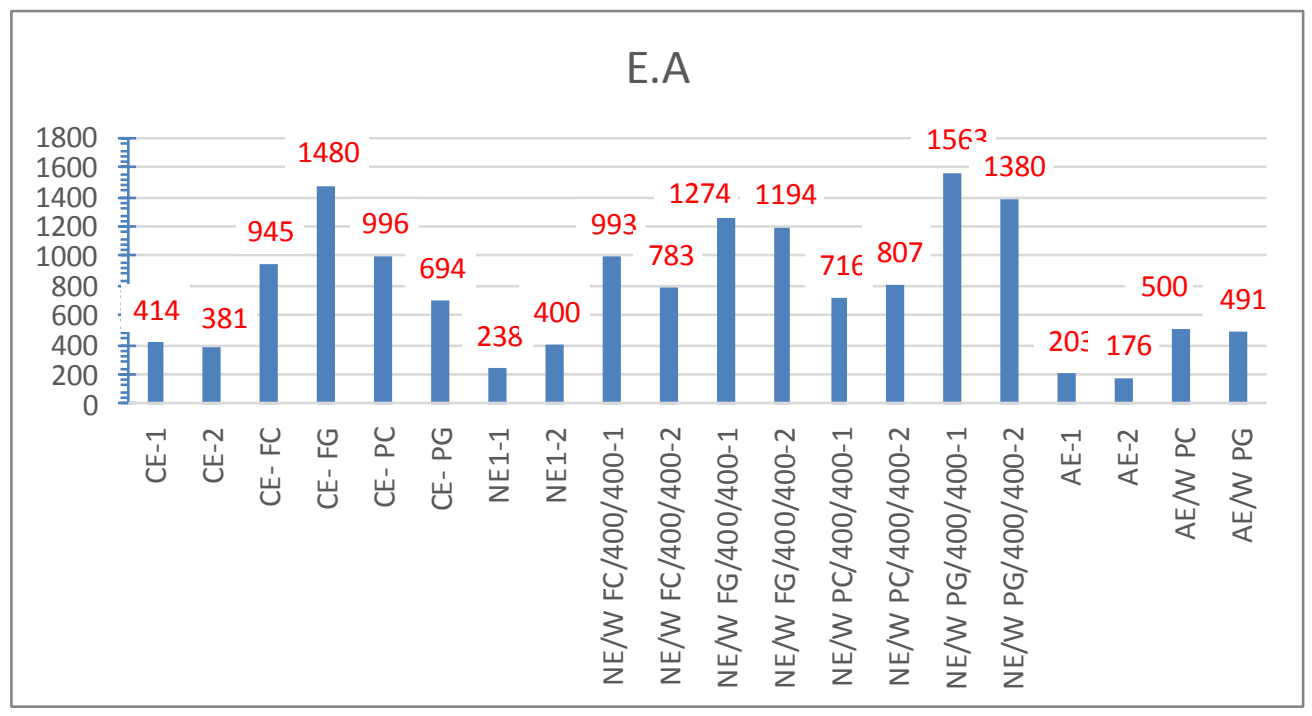

Fig.21: the energy absorption for tested specimens.

Beams corroded were given lower energy absorption than control beam (CE-1). The percentage of decrease of the energy absorption for natural corrosion process (NE-1) relative to the control beams (CE-1) was about $42 \%$ and, $57.5 \%$ for galvanostatic corrosion process (AE-2).

Beams reinforced with FRP were given higher energy absorption than control beam (CE-1). Beams were wrapped with GFRP given higher energy absorption than beams wrapped with CFRP.

\subsection{Flexural Serviceability Load:}

The Flexural serviceability load (S.L) was calculated from the load-deflection curves. It is defined as the load corresponding to deflection equal to the span of the beam $(1000 \mathrm{~mm})$ divided by (constant $=250)$ according to The Egyptian Code (E.C.P. 203/2007) [10]. In this study, S.L is taken at deflection $4 \mathrm{~mm}$ as shown in Table 3 and Fig.22.

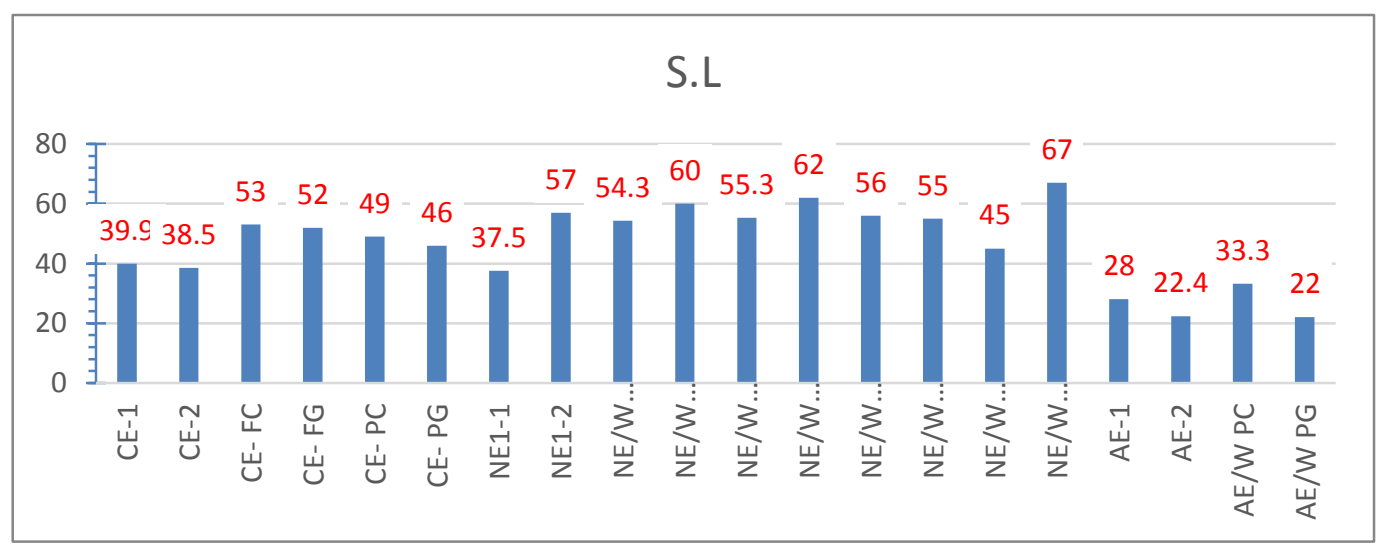

Fig.22: The serviceability load for tested specimens. 
The ratio of serviceability load to the ultimate load is $23.7 \%$ for the control beam (CE-1), $22.8 \%$ for natural corrosion beam (NE-1), and this ratio is $9.13 \%$ for galvanostatic corrosion process (AE-2). Table (4-2) represents the values of the first cracking load, serviceability load and ultimate load for all the tested beams.
The results of serviceability load show that corroded beams achieved lower serviceability load than those of the control specimens. The beams reinforced with FRP had higher serviceability load than reference beam.

Table 3: Experimental results for tested specimens.

\begin{tabular}{|c|c|c|c|c|c|c|c|c|}
\hline Group & specimens & $\begin{array}{l}\text { Pcr } \\
(k N)\end{array}$ & $\begin{array}{l}\mathbf{P u} \\
(\mathbf{k N})\end{array}$ & $\begin{array}{l}\Delta \mathrm{cr} \\
(\mathbf{m m})\end{array}$ & $\begin{array}{l}\Delta \mathrm{u} \\
(\mathbf{m m})\end{array}$ & $\begin{array}{l}\text { D.R } \\
{[\mu \mathrm{D}]}\end{array}$ & $\begin{array}{l}\text { E.A } \\
\text { (kN.mm) }\end{array}$ & $\begin{array}{l}\text { S.L } \\
(\mathbf{k N})\end{array}$ \\
\hline \multirow[t]{2}{*}{ control } & CE-1 & 20 & 52.3 & 1.65 & 8.05 & 4.88 & 414 & 39.9 \\
\hline & CE-2 & 15 & 49.6 & 1.05 & 7.65 & 7.29 & 381 & 38.5 \\
\hline \multirow[t]{4}{*}{ Strengthening } & CE- FC & 45 & 82 & 3.3 & 11.98 & 3.63 & 945 & 53 \\
\hline & CE- FG & 20 & 83.4 & 2.3 & 17.33 & 7.53 & 1480 & 52 \\
\hline & CE- PC & 30 & 77.2 & 2 & 12.93 & 6.47 & 996 & 49 \\
\hline & CE- PG & 35 & 66.4 & 2.73 & 11.05 & 4.05 & 694 & 46 \\
\hline \multirow{10}{*}{$\begin{array}{l}\text { Natural } \\
400 / 400\end{array}$} & NE1-1 & 30 & 48.6 & 3.19 & 6 & 1.88 & 238 & 37.5 \\
\hline & NE1-2 & 30 & 60.2 & 1.3 & 6.14 & 4.72 & 400 & 57 \\
\hline & NE/W FC-1 & 55 & 80.5 & 4.1 & 12.11 & 2.95 & 993 & 54.3 \\
\hline & NE/W FC-2 & 70 & 84.9 & 5.1 & 9.85 & 1.93 & 783 & 60 \\
\hline & NE/W FG-1 & 55 & 86.3 & 4.03 & 15.65 & 3.88 & 1274 & 55.3 \\
\hline & NE/W FG-2 & 50 & 80.5 & 2.7 & 14.25 & 5.28 & 1194 & 62 \\
\hline & NE/W PC-1 & 45 & 75.8 & 2.9 & 10.05 & 3.47 & 716 & 56 \\
\hline & NE/W PC-2 & 50 & 79.7 & 3.5 & 10.72 & 3.06 & 807 & 55 \\
\hline & NE/W PG-1 & 40 & 73.7 & 3.4 & 21.65 & 6.37 & 1563 & 45 \\
\hline & NE/W PG-2 & 50 & 87.4 & 2.5 & 15.18 & 6.07 & 1380 & 67 \\
\hline \multirow[t]{4}{*}{ Galvanostatic } & AE-1 & 25 & 35.9 & 3.2 & 6.34 & 1.98 & 203 & 28 \\
\hline & AE-2 & 15 & 24.65 & 1.7 & 6.79 & 3.99 & 176 & 22.4 \\
\hline & AE/W PC & 20 & 50.62 & 1.9 & 10.71 & 5.64 & 500 & 33.3 \\
\hline & AE/W PG & 15 & 31.1 & 2.1 & 15.56 & 7.41 & 491 & 22 \\
\hline
\end{tabular}

Pcr : the first crack load; $\Delta$ cr: Deflection at first crack load.

$\mathrm{Pu} \quad$ : the ultimate load; $\Delta \mathrm{u}$ : Deflection at ultimate load.

D.R: Ductility Ratio $[\mu \mathrm{D}]$; E.A: energy Absorbing; S.L: serviceability load

\subsection{The failure mode:}

For all specimens, the first crack, cracks propagation, and plane of failure were observed to investigate the cracking behavior and mode.

UN wrapped, all beams failed by shear failure with diagonal tension cracks increasing in ultimate load to fracture in the concrete at one sides as shown in fig. 23 .
Scheme I, all beams after wrapping failed by flexure failure in middle span between two points of loading by fraction in concrete and fibre. As the applied load increased, the developed cracks propagated rapidly from the tension side towards the compression side as shown in fig. 24.

Scheme II, Some of beams after wrapping failed by flexure failure in middle span between two points of loading by fraction in concrete and fibre. As the applied load increased, the developed cracks propagated rapidly from the tension side towards the compression side as shown in fig.25. (a), and others failed by shear failure with diagonal tension cracks increasing in ultimate load to fracture in the concrete at one sides as shown in fig.24. (b). The failure mode of all beam specimens indicated in table. 2 . 


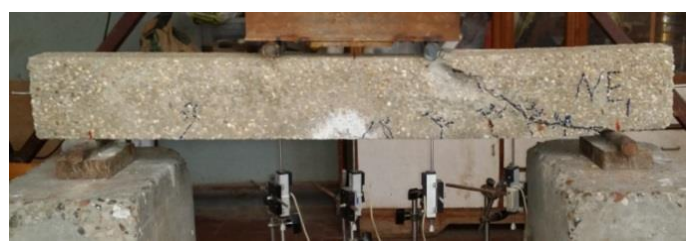

fig.23: shows failure mode of un wrapped

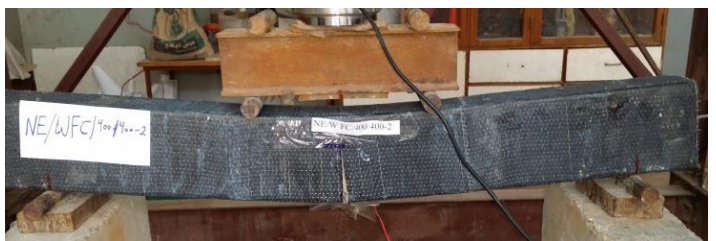

fig.24: shows failure mode of Scheme I

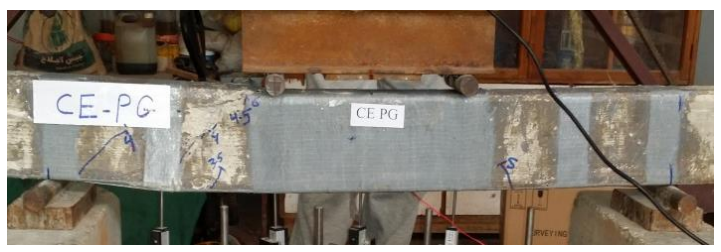

(b) shear failure

(a) Flexure failure

fig.25: shows the failure mode of scheme II.

\section{CONCLUSION:}

Based on the investigation and experimental results described, a number of conclusions may be considered for FRP wrapping to corroded beams. The factors to be taken into account are ultimate load, deflections, ductility ratio, energy absorption, and serviceability load. The findings are summarized below.

In general, FRP wrapping provided greater ease of application, make beams more ductility, additional flexural reinforcement that refers to FRP act as confinement material as well.

The deflection of the repaired beam was less for each load case compared to the un repaired beam, the repaired beams suffered higher deflection compared to the reference beam, and this eventually shows the considerable increment in stiffness.

The FRP wrapping showed more deflection during concrete failure so more warning and saving of lives before failure.

The curves indicate that the deflection of the CFRP repaired beam was less for each load case compared to the GFRP repaired beam, CFRP was better than GFRP in deflection.

At galvanostatic corrosion damage, the curves indicate that CFRP contributed to the restoration in strength of corrosion damaged beams but The GFRP cannot contributed to the restoration in strength of corrosion damaged beams to control beam. So we should use number of layer more than one layer and use scheme I instead of scheme II when use FRP to the restoration in strength in future research and follow the results.
The corroded un wrapped specimens showed higher reduction in ductility when compared with their corresponding reference without corrosion (control).

Beams corroded were given lower energy absorption than control beam. Beams reinforced with FRP were given higher energy absorption than control beam.The percentage of decrease of the energy absorption for natural corrosion process (NE-1) relative to the control beams (CE-1) was about $42 \%$ and, decrease $57.5 \%$ for galvanostatic corrosion process (AE-2).

The results of serviceability load show that corroded beams achieved lower serviceability load than those of the control specimens. The beams reinforced with FRP had higher serviceability load than reference beam .The ratio of serviceability load to the ultimate load is $23.7 \%$ for the control beam (CE-1), $22.8 \%$ for natural corrosion beam (NE-1), and this ratio is 9.13\% for galvanostatic corrosion process (AE-2).

Future work will investigate the FRP repair of corrosion-damaged concrete specimens which is more realistic of field conditions. The results in this paper provided important benchmark data.

\section{REFERENCES:}

1. ACI Committee 222. (1996). Corrosion of Metals in Concrete, ACI 222R-96, American Concrete Institute, Detroit, Michigan, 29 pp.

2. Bonacci, J. F. and Maalej, M. (2000). Externally bonded fibre reinforced polymer for rehabilitation of corrosion damaged concrete beams. ACI Structural Journal, 97(5), 703-711.

3. Sherwood, E.G. and Soudki, K.A., (2000). Rehabilitation of Corrosion Damaged Concrete 
Beams with CFRP Laminates- Pilot Study, Composites Part B: Engineering, Vol. 31, pp.453459.

4. Masoud, S. and Soudki, K.A., (2001). Rehabilitation of Corrosion-Damaged Reinforced Concrete Beams with CFRP Sheets, International Conference on FRP Composites in Civil Engineering, 12-14 December, Hong Kong, Elsevier, pp. 1617-1624.

5. Debaiky, a., green, m., and hope, b., (2002). 'Carbon Fiber Reinforced Polymer Wraps for Corrosion Control and Rehabilitation of Reinforced Concrete Columns,' ACI Materials Journal, Vol. 99, \# 2, March, pp. 129-137.

6. Masoud, S. and SOUDKI, K.A., 2006. Evaluation of Corrosion Activity in FRP Repaired RC Beams, Cement and Concrete Composites, Volume 28, Issue 10, pages 969- 977.

7. El-Maaddawy, T., Soudki, K. and Topper, T. (2007). Performance evaluation of carbon fiber reinforced polymer repaired beams under corrosive environmental conditions, ACI Structural Journal, 104(1), 3-11.
8. Al-Hammoud, R., Soudki, K. and Topper, T.H. (2011). Fatigue flexural behavior of corroded reinforced concrete beams repaired with CFRP sheets. Journal of Composites for Construction, 15(1): 42-51.

9. P. K. M. Moniruzzaman, 2013.Numerical Investigation of The effectiveness of FRP and TRM in Repairing Corrosion Damaged Reinforced Concrete Beams.

10. E.C.P. 203/2007, 2007, Egyptian Code of Practice: Design and Construction for Reinforced Concrete Structures, Research Centre for Houses Building and Physical Planning, Cairo, Egypt. 